will confront our civilization as a result of genetic engineering", will be the most difficult ever, and that their solution will only be complicated if those responsible for original discoveries make commercial links with industry.

The subcommittee last week found a more congenial witness in Dr Donald Kennedy, president of Stanford University, who earlier this year was advocating a "second Asilomar conference" on the problems of universityindustry relationships. Kennedy, who more recently has been back-pedalling on this proposal, told the subcommittee last week of the ambivalence of research universities towards proposals for industrial support in the present climate of stagnant federal budgets. Well-ordered agreements, he said, could be beneficial, but he also pointed to the dangers of conflicts of interest, secrecy and the distortion of research training.

Universities are perhaps more than usually aware of these problems because of the advocacy of the virtues of industrial support for the research universities by the National Science Board.

\section{Exploiting research}

\section{Stanford rules}

\section{Washington}

A proposal for regulating the commercial activities of members of the Stanford University faculty is to be put to the Academic Senate at its meeting in September. One of the proposals is that members of the faculty should disclose details of consultancy agreements with commercial organizations if there are reasons to expect that conflicts of interest have arisen.

The new scheme has been worked out by a committee under Dr Ingram Olkin, professor of statistics and education at Stanford, which has recommended that the university should not invest in commercial ventures set up to exploit the results of research carried out at Stanford "if any current Stanford faculty member participates" either as a shareholder or as a manager. Similarly, the university would not accept stock in such a company as part of a licensing agreement.

The proposals have been stimulated by the recent interest in the commercial exploitation of genetic manipulation, to which several members of the Stanford faculty are in a position to contribute. But it is acknowledged that similar problems may arise in other fields, the development of computer software for example.

The case for a distant relationship between the university and commercial enterprises in which faculty members are involved is based on the fear of the conflicts of interest that could arise in making faculty appointments and promotions, allocating space and settling faculty salaries, the danger that graduate

\section{Yugoslavs to resign}

Dr Pavle Savic, President of the Serbian Academy of Arts and Sciences since 1971 , has resigned in protest against the conduct of recent elections to the Academy. His resignation, which takes effect from the academy meeting of 28 May, came as no surprise - it had been openly discussed in the Yugoslav press for the preceding three weeks.

According to Dr Savic, he resigned because of the election of someone who had served several years' rigorous imprisonment as a "cominformist". He had been informed of this one month before the elections. On checking the allegation and finding it true, Dr Savic notified the appropriate Academy officials. But the election went ahead and "the "cominformist" was elected. The 'next day, Dr Savic announced his intention to resign. Two vice-presidents and the general secretary of the academy also resigned; they, however, will serve out their full term of office (until the end of the year) to maintain continuity of the academy's activities.

Dr Savic's walk-out, seven months before his term of office ended, is widely seen as a protest, not merely against the election, but against the prevailing atmosphere in the academy. A physicist, he had hoped, to build up the research side of the academy, concentrating on modern trends including laser physics, solid-state electronics and molecular biology. He was particularly keen to bring in younger scientists into the academy's institute. Most members, however, showed little enthusiasm for his plans.

Vera Rich

education might be distorted and the possibility that the university's external reputation might be affected adversely.

The committee also advocates a change in the method by which the rewards from agreements for the licensing of patents are shared out. At present, if Stanford research leads to a patent, the income is divided equally between the researcher, his or her department and the university as a whole. It is now suggested that if the income from some invention should exceed one half of a department's annual budget, the two-thirds of the royalty income not due to the inventor should be paid into a research fund from which all departments at Stanford could hope to benefit.

The committee has obviously been cautious, perhaps even overcautious, in its approach to consultancy agreements. At present, academics are required to disclose the amount of time they spend in this way, which must not exceed 13 days a quarter. There is no mechanism for monitoring this gentleman's understanding. In future, if the faculty agrees, faculty members may have to disclose, who they work for, and for how long.
Tropical disease finance World Bank acts

After a plea by Mr Robert McNamara, who resigns as president of the World Bank on 30 June, the bank governors are expected to agree this week to contribute $\$ 2.48$ million ( $£ 1.25$ million) to the Special Programme for Research and Training in Tropical Diseases (TDR) of the World Health Organization (WHO).

Previously, the bank has been willing to act merely as a financial adviser and banker to TDR, as one of the programme's three co-sponsors. (The others are WHO and the United Nations Development Programme.) The bank's main concern is with development loans, and it has been exploring for more than a year how to refine its policy towards the direct support of research. That review is not complete, but McNamara thought it well enough advanced that a commitment should now be made to the tropical disease programme. He carried his executive board with him, and their recommendation has now to be approved by the governors - the nations which fund the bank. There is not expected to be any opposition.

The support for TDR comes at an opportune time. First firmly established in 1977, and dealing with six diseases - malaria, schistosomiasis (bilharzia), trypanosomiasis (sleeping sickness), leishmaniasis, leprosy and filariasis - TDR's funds first grew rapidly but have now become roughly static at about $\$ 24$ million ( $\$ 12$ million) a year. Moreover Britain, which was contributing around $£ 600,000$ a year (but actually received back more in research grants, according to WHO), announced last December that it could not pay its 1981 contribution - shocking the 25 other contributing governments, many of which see little or no return in terms of research carried out in their countries.

According to the Canadian chairman of the TDR Scientific and Technical Advisory Committee, Dr A. B. Morrision, the effectiveness of the programme could be "crippled in the short term" if inflationary pressures are not compensated for; and in the long term, additional resources must be mobilized to permit large-scale trials of new tools for prevention and treatment now being developed.

Even so, Britain's contribution to TDR for the present year is definitely cancelled, says the Overseas Development Administration (ODA). And although next year's is "under review", the ODA's $£ 1,000$ million of aid money this year will fall by 5 per cent a year for the next three years, making a recovery of the TDR contribution less and less likely. This should not be taken as an implicit criticism of TDR, say ODA officials. On the contrary, the programme is the best managed of all the WHO special programmes, they say, thus putting a cloud over the two remaining programmes still 
supported by ODA.

British policy is to cut multilateral, special programme aid hardest, for the government's aim is to maintain direct core subscriptions to international agencies (such as the World Bank and the United Nations Development Programme), while stressing bilateral aid which is inevitably under closer British political and economic control.

Robert Walgate

\section{Armadillos fight leprosy}

The safety and ethics panel of the World Health Organization (WHO) is likely to agree within the next few months on immunization trials with a new leprosy vaccine made from the liver and spleen of infected armadillos. The trials would be conducted from January to September 1982 in the United States, United Kingdom and Scandinavia to avoid criticisms of uncontrolled drug testing in third world countries.

The objective will be to induce $85-90$ per cent immunity to the causative agent of leprosy (Mycobacterium leprae) as judged by immune reactions to lepromin, a preparation of killed $M$.leprae obtained from infected human ear-lobes.

The vaccine has been a long-standing objective of the WHO Special Programme for Research and Training in Tropical Diseases (TDR). The snag is that it depends on culturing the bug in armadillos, whose low body temperature allows growth of the organisms, and some have questioned whether it will ever be possible to breed enough armadillos to vaccinate the 2,000 million or so of the human population potentially at risk.

Dr Barry Blum of the Albert Einstein College of Medicine in New York, who heads the TDR leprosy immunization project, says, however, that armadillos are such prolific generators of M.leprae that the numbers should be sufficient. A mixed vaccine made from human tissue yields immunity with a single dose of $6 \times 10^{8}$ killed bacteria. An armadillo three years after infection produces about $2.5 \times 10^{12}$ bacteria in the liver and spleen. If the vaccine produced from them is as effective as the human one, each armadillo should yield 4,000 doses. WHO now has 250 animals used for research and the forthcoming trial, but there is a population of 10 million armadillos in the southern United States.

The adequacy of the supply depends directly on the dose required to produce immunity. One shot must be $85-90$ per cent effective to avoid the need for repeated injections. The availability of the vaccine would also depend on the efficiency of extraction from armadillo tissue, a problem which has been given to the Wellcome Laboratories in the United Kingdom to resolve. Then leprosy is such a slow-moving disease that proof in the field against infective organisms will take ten years.
US solar energy

\section{No silver lining}

\section{Washington}

The Solar Energy Research Institute at Golden, Colorado, has been flung further into limbo by the arrival of the new Administration, which is now trying to respond to a demand from the General Accounting Office that the objectives of the institute should be spelled out. Most probably the institute, once the spearhead of President Carter's ambition that a fifth of United States energy consumption at the end of the century should be solar energy, will be asked to concentrate on long-term research, abandoning the commercial demonstration of solar energy devices. The present budget of $\$ 130$ million is likely to be cut by a half, and between 100 and 200 of the present staff of 770 will probably lose their jobs.

The brief history of the institute, set up in 1977 and managed for the Department of Energy by the Mid-West Research Institute of Kansas, is a tale of muddle. Originally, there was to have been a staff of 1,200 engaged on long-term research, development and the commercial demonstration of devices able to win energy from the Sun. In part, the institute has been the victim of the success of some applications of solar energy. Solar water heaters, large and small, and small hydroelectric plants are multiplying throughout the United States - the Department of Energy is embarrassed by more than 1,000 applications from private companies and individuals to build hydroelectric plants. With the Administration committed to the view that commercial developments should be the responsibility of commercial organizations, not the government, the institute's demonstration programme has become vulnerable. So much seemed clear during a visit to Golden by officials of the Department of Energy last month.

Even when the axe falls, in the next few weeks, the rump of the institute is unlikely to be reassured about its future. Although the institute is now nearly four years old, the special building (on a 300-acre site offered by the Government of Colorado) seems as far off as ever. In a sharp letter to the Secretary of Energy at the end of April, the General Accounting Office asked that further design should be postponed until the department had decided what the longterm role of the institute should be, and that even the use of the 300 -acre site for experimental rigs should wait on this definition. One snag is that the offer of the site expires in April 1982.

The letter is scathing about the planning of the building. Although authority for a laboratory was included in the 1974 Solar Energy Act, the estimated cost of $\$ 132$ million (in 1978) was an unwelcome surprise. Successive Secretaries of Energy have sought to limit the cost of the buildings to $\$ 98$ million (in 1979) and $\$ 75$ million (in 1980). The General Accounting Office points out that the original scheme for making the building 80 per cent selfsufficient in its own energy requirements was based on the use of active and passive solar power devices which had not been proved and which were not all costeffective. Meanwhile the institute's staff camps out in rented of fice accommodation costing \$5 million a year, and has spent substantial sums on the conversion of offices to laboratories.

Since 1977, the institute's research programme has been trimmed by the removal of general responsibility for the exploitation of biomass, but it remains responsible for the use of methanol as a liquid fuel - a motor vehicle driven by hydrogen derived from the catalytic decomposition of methanol will be demonstrated later in the year. The institute is also confident that it will be able to produce silicon-based solar cells yielding power at a cost of 70 cents per watt by the end of this decade, roughly a tenth of the present cost of solar cells.

\section{European Space Agency \\ Delays in space}

For the second time this year, the European Space Agency (ESA) may be hamstrung by a change of plans within the United States National Aeronautics and Space Administration (NASA). This time, the possible casualty is Spacelab, ESA's manned space laboratory due to be launched on the space shuttle. Spacelab's first flight could be delayed, or its success reduced, if the Department of Defense persuades NASA to modify and thus delay the launch of the second of the two satellites intended to form the basis of a new data collection system.

The Tracking and Data Relay Satellite System (TDRSS) will eventually replace much of the worldwide network of tracking stations for relaying data from the space shuttle and satellites in low Earth orbit. Two tracking satellites, to be launched into geosynchronous orbits from early shuttle flights, were to transmit data from almost any position in a low Earth orbit to a central receiving station at White Sands, New Mexico. The original plan was to iaunch the first tracking satellite on the sixth shuttle flight, the second in June 1983 and Spacelab itself in September 1983. But now the Department of Defense has asked that extra coding should be built into the second satellite which could delay the launching until after that of Spacelab. One possibility is that the first Spacelab flight would be brought forward to June 1983 and the second tracking satellite launched only in September 1983.

If NASA accedes to this request, ESA would have the choice of either flying the first Spacelab payload with only one tracking satellite in service or of delaying the flight until the spring of 1984. One 